\title{
Evaluation of the Relationship Between the Patient Safety Culture and Medical Error Attitudes of the Pediatric Nurses
}

\author{
Dilek Kucuk Alemdar ${ }^{1} \mathbb{D}$, Gamze Yilmaz ${ }^{2}$ \\ ${ }^{1}$ Ordu University, Health Sciences Faculty, Nursing Department, Ordu, Turkey \\ ${ }^{2}$ Ibrahim Cecen University, School of Health, Nursing Department, Agri, Turkey \\ Correspondence Author: Dilek Kucuk Alemdar, Gamze Yilmaz \\ E-mail: dilekkucuk@atauni.edu.tr
}

Received: $07.03 .2019 \quad$ Accepted: 06.08 .2019

\begin{abstract}
Objective: This study was conducted descriptively so as to determine the relationship between the patient security culture and medical error attitudes of the nurses.

Methods: The population of the study was conducted between 10 August and 25 August 2017 that the data were collected in the hospitals in the eastern Turkey of 82 nurses working in children's services. The sampling selection method was not used in this study, but 68 nurses that were accessed between the dates and that accepted to participate in the study voluntarily were included in the sampling of the study. "Descriptive Information Form" in which the socio-demographic information of the nurses is assessed, "Patient Security Culture Scale (PSCS)" and "Scale of Attitudes towards Medical Errors (SAME)" were used as data collection tools in the study.

Results: Nurses received an average score of $3.71 \pm 0.27$ from PSCS, and an average score of 3.02 \pm 0.44 from SAME. A significant relationship was determined between the education status of the nurses and their PSCS total score $(p<0.05)$. As a result of the correlation analysis it was determined that there was a positively significant relationship between the PSCS score and SAME scores of the nurses, and as their PSCS scores increased, their SAME scored increased aswell.

Conclusion:Evaluation of the current status by conducting regular measurements in regard to patient security in institutions and should be make improvements accordingly. Also, nurses should take responsibility in patient safety and improvement of patient safety culture should be the main priority of the institutions.
\end{abstract}

Keywords: Patient Safety, Medical Error, Pediatric, Nurses

\section{INTRODUCTION}

The patient safety culture should be established in order to ensure patient safety in health institutions (1). The patient safety culture is defined as the transparency in error reports and a systematic approach for preventing medical errors and honesty (2). The patient safety culture is a multidisciplinary structure that combines information and communication technologies (3). It also contains value judgments, beliefs and rules on what is important in the organization and how to act about patient safety $(4,5)$. The Institute of Medicine (IOM) which is known as the most influential body to guide medical practice in the United States, defines patient safety as the prevention of harm to patients. It has been reported that this is possible with a care system that is based on a safety culture that includes health care workers, institutions and patients and prevents errors and takes lessons from the errors (6). Turkey National Patient Safety Foundation defines patient safety as the prevention of medical service related errors and the elimination or reduction of the damages caused by these errors $(7,8)$.
According to the latest report published by the National Medical Institute in the United States in 2000, 44,00098,000 people die due to medical errors in US hospitals every yeary. This figure reveals the importance of errors in health sector (9). The Joint Commission on Accreditation of Healthcare Organizations (JCAHO) defines the concept of medical error as a harm to the patient as a result of an appropriate and unethical behavior by a healthcare professional and inadequacy and negligence in occupational applications (10). Similarly, the applications which elongate increase the length of stay of patients, deteriorate patients' health, harm of patients or lead to death due to lack of knowledge, inexperience, lack of interest or the technology, are considered as medical errors (11). The issue of medical errors is a growing problem in health. In a study, it was found that the ratio of those who believed that a medical error was $34 \%$ in the United States, 30\% in Canada, 27\% in Australia, $23 \%$ in Germany and $22 \%$ in the UK (12). 
The pediatric patient safety is a dynamic and complex subject as a result of the physiological and developmental characteristics of children. The growth and development are very fast during the first years of life and the maturation continues at a slow pace throughout the late childhood. This situation increases the risk of error due to children's cognitive and physical development. On the other hand, children, especially the children who are small and can not communicate verbally, are dependent on adults to meet their health needs. These differences are more influential in higher number of application errors in children than that in adults $(13,14)$. Clinical differences should be taken into consideration for patient safety. Pediatric clinics need more effort in patient safety. Hospital environment is different from the familier environment of infants and children. It is a danger for health of them and a threat that prevents them from their normal environment and functions for a certain period of time. Therefore, a safe and positively influential physical environment is known to affect the infant and child physically, mentally and socially; it also shorten the process of recovery and hospital stay $(15,16)$. Malpractice in nursing is impairment of patients due to tyhe lack standard application during nursing care. It is very important that pediatric nurses know the conditions that increase the risk of malpractice and take the necessary precautions in order to prevent to harm pediatric patients and their families and to protect themselves against the law. For reducing the risk of malpractice, pediatric nurses should keep away from administering a drug that they do not know well; they should consult a reliable source about this drug and negotiate with the physician (13).

The main condition for preventing medical errors and providing safe health care, is the establishment of the patient safety culture in health care institutions (17). The patient safety culture requires that all healthcare staff have the responsibility of patient safety culture in terms of the reporting of the factors that threaten patients and staff' safety and medical errors. It also requires the maintenance of the diagnosis, treatment and care services without causing harm to patients $(18,19)$. In this context, it is very important to determine nurses in pediatric clinics have a tendency to medical error in which subjects. It is very important to detect medical errors at the right time before they cause serious harm to human health, to reveal their causes and to develop suggestions for their solution. For this purpose, determining the attitudes of the nurses who spend a long time with the patients and take care of them, towards the medical errors, especially towards the reporting of errors enable the necessary arrangements for the safe care. In this respect, the study was planned to determine the patient safety culture and medical error attitudes of pediatric nurses.

\section{METHODS}

\subsection{Study design}

This study was carried out as a cross-sectional, descriptive relational survey to determine the relationship between the pediatric nurses' patient safety culture and medical error attitudes. Relational survey model was used because it was desired to be described as it was without changing the situation. Relational survey models are research models which aim to determine the existence and/or degree of interchange between two or more variables.

\subsection{Setting}

The population of the study was conducted between the dates 10 August and 25 August 2017 that the data were collected in the hospitals in the eastern Turkey of 82 nurses working in children's services.

\subsection{Sample}

The universe of the study consisted of 82 nurses working in pediatric clinics in the hospitals in the eastern provinces of Turkey at the time the study. The sample selection method was not used in the study; 68 nurses who were reached at the the time of the study and who accepted to participate in the study were included in the sample of the study. The data were collected by using the Introductory Information Form, Patient Safety Culture Scale (PSCS) and Scale of Attitudes towards Medical Errors (SAME).

\subsection{Research Questions}

- Is there a relationship between patient safety culture and medical error attitudes of pediatric nurses?

- Is there a relationship between sociodemographic, workrelated characteristics and medical errors and patient safety culture and medical error attitudes?

\subsection{Instruments}

2.5.1. Descriptive Information Form: A twenty item questionnaire form which was prepared by the researchers was used to collect the data. This form included the questions about demographic data, professional knowledge, patient safety and medical errors.

2.5.2. Scale of Attitudes Towards Medical Errors (SAME): It is a 16-item scale which was developed by Gülec and Intepeler to determine the attitudes of health care professionals' attitudes towards medical errors. The Scale of Attitudes Towards Medical Errors is a 5-point Likert-type scale. It consists of three sub-dimensions as medical error perception (1st and 2nd items), medical error attitude (3. 8. 10. 11. 12. 13. and 14. items) and the causes of medical errors. It's scoring is (1) I strongly disagree, (2) I disagree, (3) I am 
neutral, (4) I agree and (5) I totally agree. Two items in the scale (item 10th and 13th) are scored in reverse. In scoring, the score from the whole scale is taken; the scale score is obtained by dividing the raw score by the number of items in the scale. In the sub-dimension score calculation, the total sub-dimension score is calculated; the sub-dimension is divided by the number of items; the score is rated between 1-5. The cut-off point of the scale has been determined as 3 . The medical error attitudes of health care professionals who have a score less than 3 points on the scale are considered to be negative, while medical error attitudes of health care professionals who score 3 or higher are considered as positive. A negative attitude means that health care professionals are less aware of the importance of medical errors and medical error reporting. The positive attitude shows that health care professionals' awareness about the importance of medical error and error reporting is high. The scoring and assessment of the whole scale is accepted for all sub-dimensions of the scale in the same way. In the study of Güleç and Intepeler (20), the Cronbach's alpha reliability coefficient of the Attitude Scale for Medical Errors was found as 0.75 . Cronbach's alpha coefficient ranged from $r=.73$ to .86 in this study.

2.5.3. Patient Safety Culture Scale (PSCS): For the assessment of the patient safety culture, the PSCS was developed by Türkmen et al. The validity-reliability study of this scale was conducted in the nursing group, it consists of 51 items. The PCS consists of 5 sub-dimensions as management and leadership (17 items), staff behavior (14 items), unexpected events and error reporting ( 5 items), staff training ( 7 items) and care environment ( 8 items). The PSCS is a 4-point likert type measurement tool. The effectiveness of patient safety practices is evaluated based on the scores ranging from "1 Strongly disagree", 2 "Disagree", "3 Agree" to "4 Strongly agree". In the analysis of the score on the scale, the increase in the mean score up to 4 shows positive patient safety culture and the decrease to 1 indicates the presence of negative patient safety culture. Turkmen et al.(21) found that the Cronbach's alpha reliability coefficient was found to be 0.97 for the whole scale and 0.83-0.92 for the sub-dimensions. In this study, the Cronbach's Alpha reliability coefficient of the scale was found as 0.97 while the coefficient of the subdimensions ranged between 0.85 and 0.94 .

\subsection{Ethical Statement}

The ethical committe approval and required permissions were obtained from the Ibrahim Cecen University Ethics Committee (No: 95531838-050.99) and the Provincial Health Directorate and the institutions. The purpose of the study was explained to the nurses and information was given about their right to withdraw their consent at any time. After the verbal permissions of the participants were obtained, the questionnaire form was applied. The principles of the Declaration of Helsinki were agreed before the forms were applied.

\subsection{Data Collection}

The verbal permissions of the nurses were obtained after the explanation of the aim of the study to them. After that, the forms were applied to the nurses who accepted to participate in the study with face to face interview method by the researchers in the nurse room. It took approximately 10-15 minutes.

\subsection{Statistical Analysis}

The analyzes were performed with Windows Statistical Package for Social Sciences (SPSS) 21.0. The normality of the data was evaluated by using Shapiro-Wilk test. Data was not normally distributed. The descriptive statistical methods such as number, percentage, mean and standard deviation were used in the analysis of the data while Kruskal Wallis Test and Mann Whitney $U$ test were used for the comparison of SAME and PSCS scores of the groups. Pearson's correlation coefficient was used for the analysis of the relationship analysis between age, occupational experience, working time in pediatric service and SAME, PSCS scores. The results were evaluated at $95 \%$ confidence interval and $p<0.05$ was considered as statistically significanct.

\section{RESULTS}

$83.8 \%$ of the nurses included in the study were female; $48.5 \%$ of them had an undergraduate education $50.0 \%$ of them were single; $50 \%$ of them worked shifts. The mean age of the nurses was $26.88 \pm 4.87$; their mean time of professional experience was $6.01 \pm 4.04$ years; $75 \%$ of them enjoyed their profession. $36.8 \%$ of the nurses in the study had previously encountered a medical error; $19.1 \%$ of them stated that they made a medical mistake during their career. $45.6 \%$ of the nurses believed that the cause of medical error is high workload/low number of staff; $48.5 \%$ of them thought that the most common drug administration error was wrong dose (Table 1).

In Table 2, the mean scores of the pediatric nurses on the whole SAME and PSCS and on the subdimensions of them were given. The mean score of the nurses on the whole SAME was 3.02 \pm 0.44 . Their mean score on the Medical Error Perception sub-dimension was 1.96 \pm 0.48 ; their mean score on the Medical Error Attitude sub-dimension was 3.53 \pm 0.73 ; their mean score on the Medical Error Causes sub-dimension was $3.59 \pm 0.58$. The mean score of the nurses on the whole PSCS scale was $2.71 \pm 0.27$. Their mean score on the Management and Leadership sub-dimension was 2.60 \pm 0.45 ; their mean score on the Staff Behavior sub-dimension was 2.77 \pm 0.43 ; their mean score on the Unexpected Case and Error Reporting sub-dimension was $3.02 \pm 0.77$; their mean score on the Employee Training sub-dimension was 2.58 \pm 0.68 ; their mean score on the Care Environment subdimension was $2.60 \pm 0.48$. 
Table 1. Distributions of nurses'sociodemographic, work-relatedcha racteristicsandmedicalerrors

\begin{tabular}{|c|c|c|c|}
\hline \multicolumn{2}{|l|}{ CHARACTERISTICS } & $\mathbf{N}$ & $\%$ \\
\hline \multicolumn{2}{|l|}{ Age } & & \\
\hline \multicolumn{2}{|l|}{$19-25$} & 32 & 47.1 \\
\hline \multicolumn{2}{|l|}{$26-32$} & 30 & 44.1 \\
\hline \multicolumn{2}{|l|}{$33-39$} & 6 & 8.8 \\
\hline \multicolumn{2}{|l|}{ Gender } & & \\
\hline \multicolumn{2}{|l|}{ Female } & 57 & 83.8 \\
\hline \multicolumn{2}{|l|}{ Male } & 11 & 16.2 \\
\hline \multicolumn{2}{|l|}{ Education Level } & & \\
\hline \multicolumn{2}{|l|}{ High School } & 18 & 26.5 \\
\hline \multicolumn{2}{|l|}{ Associate Degree } & 13 & 19.1 \\
\hline \multicolumn{2}{|l|}{ Undergraduate } & 33 & 48.5 \\
\hline \multicolumn{2}{|l|}{ Postgraduate } & 4 & 5.9 \\
\hline \multicolumn{2}{|l|}{ Marital Status } & & \\
\hline \multicolumn{2}{|l|}{ Single } & 34 & 50.0 \\
\hline \multicolumn{2}{|l|}{ Married } & 34 & 50.0 \\
\hline \multicolumn{2}{|l|}{ Child bearing Status } & & \\
\hline \multicolumn{2}{|l|}{ Yes } & 11 & 16.2 \\
\hline No & & 57 & 83.8 \\
\hline Working Type & & & \\
\hline Full Time, On Days & & 34 & 50.0 \\
\hline Shift & & 34 & 50.0 \\
\hline Occupational Enjoyment & & & \\
\hline I enjoy & & 51 & 75.0 \\
\hline I don't enjoy & & 5 & 7.4 \\
\hline Neutral & & 12 & 17.6 \\
\hline Have you ever encountered a medical error? & & & \\
\hline Yes & & 25 & 36.8 \\
\hline No & & 43 & 63.2 \\
\hline If yes, who made the medical error? & & & \\
\hline Nurse & & 19 & 76.00 \\
\hline Physician & & 6 & 24.00 \\
\hline What is the cause of medical errors according & you? & & \\
\hline High work load/low number of staff & & 31 & 45.6 \\
\hline New staff /Poor practice & & 8 & 11.8 \\
\hline Loading non-tasking jobs & & 11 & 16.2 \\
\hline Stress/Fatigue /Exhaustion/Busy schedule & & 18 & 26.5 \\
\hline Have you ever made any medical errors in you & career? & & \\
\hline Yes & & 13 & 19.1 \\
\hline No & & 55 & 80.9 \\
\hline $\begin{array}{l}\text { The most common drug administration error } \mathrm{u} \\
\text { countered }\end{array}$ & hich you en- & & \\
\hline Wrong administration way & & 10 & 14.7 \\
\hline Wrong administration time & & 11 & 16.2 \\
\hline Wrong patient & & 4 & 5.9 \\
\hline Wrong dose & & 33 & 48.5 \\
\hline Wrong medication & & 10 & 14.7 \\
\hline Causes of patients falling at your service & & & \\
\hline Physical and consciousness state of the patient & & 6 & 5.9 \\
\hline Not using the bed edge bars & & 39 & 57.4 \\
\hline Wet floors & & 6 & 5.9 \\
\hline Carelessness of staff & & 8 & 11.8 \\
\hline Having no companion & & 9 & 13.2 \\
\hline Total & & 68 & 100.0 \\
\hline Age (Mean士SD) & $26.88 \pm 4.87$ & & $\begin{array}{l}(\min =19, \\
\max =39)\end{array}$ \\
\hline Length of Professional Experience (Mean \pm SD) & $6.01 \pm 4.04$ & & $\begin{array}{l}(\min =1 \\
\max =20)\end{array}$ \\
\hline Working Years in Pediatric Service (Mean \pm SD) & $4.25 \pm 2.73$ & & $\begin{array}{l}(\min =1 \\
\max =11)\end{array}$ \\
\hline Total Weekly Working Hours (Mean \pm SD) & $53.10 \pm 15.59$ & & $\begin{array}{l}(\min =40, \\
\max =72)\end{array}$ \\
\hline Daily Number of Patients (Mean $\pm S D$ ) & $21.00 \pm 17.42$ & & $\begin{array}{l}(\min =2, \\
\max =30)\end{array}$ \\
\hline
\end{tabular}

$N=$ number,$S D=$ standard deviation
Table 2. The Pediatric Nurses' Mean Scores on the SAME and PSCS $(N=68)$

\begin{tabular}{|l|c|c|c|c|}
\hline & Minimum & Maximum & Mean & $\begin{array}{c}\text { Standart } \\
\text { Deviation }\end{array}$ \\
\hline SAME Total Score & 0.94 & 4.57 & 3.02 & 0.44 \\
\hline Medical Error Perception & 0.25 & 3.00 & 1.96 & 0.48 \\
\hline Medical ErrorAttitude & 1.43 & 7.86 & 3.53 & 0.73 \\
\hline Medical Error Causes & 1.14 & 4.86 & 3.59 & 0.58 \\
\hline PSCS Total Score & 1.82 & 3.49 & 2.71 & 0.27 \\
\hline $\begin{array}{l}\text { Management and Lea- } \\
\text { dership }\end{array}$ & 1.71 & 3.71 & 2.60 & 0.45 \\
\hline Staff Behavior & 1.78 & 4.11 & 2.77 & 0.43 \\
\hline $\begin{array}{l}\text { Unexpected Case and } \\
\text { Reporting Error }\end{array}$ & 1.00 & 4.10 & 3.02 & 0.77 \\
\hline Staff Training & 1.00 & 4.00 & 2.58 & 0.68 \\
\hline Care Environment & 1.33 & 3.83 & 2.60 & 0.48 \\
\hline
\end{tabular}

In Table 3, the relationship between the scores of the pediatric nurses on the whole SAME and PSCS were analyzed. As a result of the correlation analysis, a significant relationship weak and positive correlation was found between the mean score of the nurses on the SAME scale and their mean score on the PSCS scale ( $r=0.326 ; p=0.007)$. As the scores of the nurses on the whole SAME increased, their scores on the whole PSCS increased.

Table 3. Pearsoncorrelationcoefficientbetweenthepediatricnurses' scores on thewhole PSCS andSAME $(N=68)$

\begin{tabular}{|l|c|c|}
\hline & \multicolumn{2}{|c|}{ PatientSafetyCultureScale (PSCS) } \\
\hline $\begin{array}{l}\text { Scale of AttitudesTowardsMedi- } \\
\text { calErrors (SAME) }\end{array}$ & $\mathbf{r}$ & $\mathrm{p}$-Value \\
\hline
\end{tabular}

In the correlation analysis, there was no significant relationship between the mean age of the nurses, their length of professional experience, their working years in pediatric service, their total weekly working hours and their mean scores on the PSCS and SAME ( $p>0.05)$. However, a significant relationship weak and negative correlation was found between the mean daily number of patients of the nurses and their mean scores on the PSCS and SAME $(p<0.05)$. As the daily number of patients of the nurses increased, their scores on the PSCS and SAME decreased $(p<0.05)$. As a result of the analyzes (Kruskal Wallis Test and Mann Whitney U test), a significant relationship was found between the education status of nurses and their scores the PSCS $(p<0.05)$, but there was no significant relationship in terms of the total SAME score. No significant relationship was found between the marital status of the nurses, their occupational enjoyment, working type, the status of making a medical error and their scores on the SAME and PSCS ( $p>0.05)$. (Table 4). 
Table 4. Pearson correlation coefficient between the pediatric nurses' scores on thewhole PSCS andSAMEscales $(N=68)$

\begin{tabular}{|c|c|c|c|c|}
\hline & \multicolumn{2}{|c|}{ PSCS } & \multicolumn{2}{|c|}{ SAME } \\
\hline & $r$ & $p$-Value & $\mathbf{R}$ & $p$-Value \\
\hline Age (Mean $\pm S D$ ) & -0.026 & 0.835 & -0.060 & 0.629 \\
\hline $\begin{array}{l}\text { Length of Profes- } \\
\text { sional Experience } \\
\text { (Mean } \pm S D \text { ) }\end{array}$ & -0.235 & 0.273 & -0.245 & 0.044 \\
\hline $\begin{array}{l}\text { WorkingYears in } \\
\text { Pediatric Service } \\
\text { (Mean } \pm \text { SD) }\end{array}$ & -0.194 & 0.113 & -0.209 & 0.352 \\
\hline $\begin{array}{l}\text { Total WeeklyWor- } \\
\text { kingHours (Me- } \\
\text { an士SD) }\end{array}$ & +0.135 & 0.273 & +0.094 & 0.446 \\
\hline $\begin{array}{l}\text { Daily Number } \\
\text { of Patients (Me- } \\
\text { an } \pm S D \text { ) }\end{array}$ & -0.314 & 0.009 & -0.365 & 0.002 \\
\hline & \multicolumn{2}{|c|}{ PSCS } & \multicolumn{2}{|c|}{ SAME } \\
\hline & Mean $\pm S D$ & test and p & Mea & test and $p$ \\
\hline $\begin{array}{l}\text { Education Level } \\
\text { High School } \\
\text { AssociateDegree } \\
\text { Undergraduate } \\
\text { Postgraduate }\end{array}$ & $\begin{array}{l}2.50 \pm 0.20 \\
2.65 \pm 0.34 \\
2.70 \pm 0.29 \\
2.76 \pm 0.25\end{array}$ & $\begin{array}{c}\mathrm{KW}=9.72 \\
\mathrm{p}<0.05\end{array}$ & $\begin{array}{l}2.97 \\
2.99 \\
3.04 \\
3.14\end{array}$ & $\begin{array}{c}K W=0.88 \\
p>0.05\end{array}$ \\
\hline $\begin{array}{l}\text { MaritalStatus } \\
\text { Single } \\
\text { Married } \\
\end{array}$ & $\begin{array}{l}2.69 \pm 0.53 \\
2.73 \pm 0.33\end{array}$ & $\begin{array}{c}\mathrm{MWU}=397.50 \\
p>0.05\end{array}$ & $\begin{array}{l}2.97 \\
3.08\end{array}$ & $\begin{array}{c}\mathrm{MWU}=550.50 \\
\mathrm{p}>0.05\end{array}$ \\
\hline $\begin{array}{l}\text { WorkingType } \\
\text { Full Time } \\
\text { On DaysShift }\end{array}$ & $\begin{array}{l}2.65 \pm 0.26 \\
2.77 \pm 0.27\end{array}$ & $\begin{array}{c}M W U=546.00 \\
p>0.05\end{array}$ & $\begin{array}{l}2.96 \\
3.09\end{array}$ & $\begin{array}{c}M W U=422.00 \\
p>0.05\end{array}$ \\
\hline $\begin{array}{l}\text { OccupationalEn- } \\
\text { joyment } \\
\text { I enjoy } \\
\text { I don'tenjoy } \\
\text { Neutral }\end{array}$ & $\begin{array}{l}2.73 \pm 0.28 \\
2.64 \pm 0.21 \\
2.66 \pm 0.26\end{array}$ & $\begin{array}{c}\mathrm{KW}=1.57 \\
\mathrm{p}>0.05\end{array}$ & $\begin{array}{l}3.04 \\
2.88 \\
3.02\end{array}$ & $K W=7.03 p>0.05$ \\
\hline $\begin{array}{l}\text { Haveyou ever ma- } \\
\text { deanymedical } \\
\text { errors in yourca- } \\
\text { reer? }\end{array}$ & & & & \\
\hline Yes & $2.51 \pm 0.44$ & $M W U=230.00$ & 2.88 & $M W U=181.00$ \\
\hline No & $2.76 \pm 0.19$ & $p>0.05$ & 3.06 & $p>0.05$ \\
\hline
\end{tabular}

$S D=$ standard deviation

\section{DISCUSSION}

The development of safety culture in healthcare is an important component of the prevention or minimisation of medical errors. In this study which was conducted to determine the relationship between pediatric nurses' patient safety culture and their medical error attitudes, the mean score of the nurses on the whole SAME was determined as $3.02 \pm 0.44$. In the study of Gök(22) which investigated the relationship between the pediatric nurses status for reporting medical errors and their attitudes towards medical errors, the mean score of the nurses on the SAME was $3.48 \pm 0.51$. This finding is similar to our finding. Since the mean score of the nurses on the SAME was higher than 3 , it can be suggested that their attitudes towards medical errors are generally positive.
In this study, it was found that $36.8 \%$ of the pediatric nurses encountered a medical error while $19.1 \%$ of them had previously made a drug administration error. The most common type of drug administration error encountered by the nurses was determined as wrong dose (48.5\%). When the literature was searched, it was seen that the rates of encountering medical errors by nurses varied but the types and causes of medical errors were similar. In a study of Gök (22), $40.8 \%$ of the pediatric nurses reported more than one drug administration error in their clinics in a year. Ersun et al.(23) found that $61 \%$ of the pediatric nurses encountered medical errors; $48.5 \%$ of them witnessed the errors of their colleagues; the most common medical error (57.8\%) was drug administration errors. It was also determined that $27.7 \%$ of the nurses had previously made a drug administration error while the most common type of drug administration error was the wrong dose (67.8\%). In a study of Mayo and Duncan (24)it was found that $46.5 \%$ of 983 nurses made drug administration errors. In the study of Özkan et al. (25) the medical error rate was found as $35.5 \%$. The rate of witnessing the errors of the nurses was determined as $10.4 \%$ in a study of Özata and Altunkan (26). According to the study of Glaheb et al. (27) the error rate was $27.6 \%$. Young et al. (28) reported that the rate of drug administration errors was $28.2 \%$. In a study of Çırpı et al. (5), it was found that the drug administration errors was on the first place among the errors encountered by nurses with the ratio of $57.0 \%$. In a study of Madegovda et al.(29), the drug administration errors were found to be related to wrong dose (16.7\%), wrong medication $(10.0 \%)$, wrong time $(9.2 \%)$ and wrong patient (7.5\%), respectively.

In this study, $45.6 \%$ of the pediatric nurses stated that the cause of medical errors was the high workload/low number of staff. In this study, it was observed that the scores of the nurses on the SAME and PSCS decreased when the daily number of patients of them increased. In their study conducted with the pediatric nurses, Lan et al. (30) reported that the most important cause of drug administration errors (67.4\%) was low number of nurses. In their study, Sears et al.(31) analyzed 372 drug administration error reports of the pediatric nurses. According to their findings, the main three reasons for drug administration errors were high workload, distraction and ineffective communication. You et al.(32) reported that low number of nurses in each shift and the administration of similar named or labeled drugs were the main causes of drug administration errors. Parry et al. (33) reported that nurse to patient ratio was a factor in drug administration errors in their systematic review Chang and Mark (34)determined that the number of drug errors decreased when the number of the nurses in the services increased. In a Turkish study of Gök (22), it was determined that the main causes of the pediatric nurses' drug administration errors were the number of patients per nurse (92.7\%) and workload (91.1\%). In the SAME, they also reported that high number of patients (81.1\%) and the long daily working hours (83.8\%) increase the number of medical errors. Özkan et al.(35) reported that the main reason of the errors was the workload of pediatric 
nurses. In the study of Törüner and Uysal(36)which was conducted with 119 pediatric nurses, it was determined that the long working hours (68.1\%) and the number of patients per nurse $(58.8 \%)$ were the main causes of drug administration errors. According to the study conducted by Özata and Altunkan(26) high workload, low number of the nurses were the leading causes of medical errors.In the study of Ateş (37) nurses reported that the main causes of drug administration errors were high number of patients per nurse, long working hours, the lack of pediatric forms of drugs and fatigue. According to the studies in Turkey and in other countries, drug administration errors originated from the system. It is very important to detect medical errors at the right time before they cause serious harm to human health, to reveal their causes and to develop suggestions for their solution. The arrangements for the prevention of errors should be aimed at both reducing the workload of nurses and effective planning of the number of patients per nurse. For this purpose, determining the attitudes of the nurses who spend a long time with the patients and take care of them, towards the medical errors, especially towards the reporting of errors enable the necessary arrangements for the safe care $(20,22)$.

In this study, the mean score of the nurses on the PSCS was $2.71 \pm 0.27$. The mean score nearly 4 shows a positive patient safety culture. In this study, it could be considered that the perception of patient safety culture wass slightly above the medium level. In the study of Rizalar et al.(38)the mean score of the nurses on the PSCS was $2.64 \pm 0.43$. In the study of Ertürk et al.(39) the mean score of the nurses on the PSCS was 2.81 \pm 0.40 .Karaca and Arslan(40) found that the mean score of the nurses on the PSCS was $3.00 \pm 0.539$.In a study of Özdemir (41) in which another patient safety culture scale was used and the mean score ranged between 1 and 5 , the mean score of patient safety culture was found to be $3.40 \pm 0.70$. In the studies of Dursun et al.(19) and Erdağı and Özer (42) patient safety perception was found to be above the middle level.These studies support the results of our study and the nurses' perception levels about patient safety culture were above the middle level. In the study, the perception level about patient safety was not very good, therefore it showed the necessity to make improvements.

When the scores on the sub-dimensions of the PSCS were analyzed, it was found that the nurses had the highest score on the Unexpected Event and Error Reporting subdimension (3.02 \pm 0.77$)$ while they had the lowest score on the Staff Training subdimension $(2.58 \pm 0.68)$. In the study conducted by Türk et al. (43), the highest score on the patient safety dimension was reported on the Event and Error Reporting subdimension $(2.4 \pm 0.735)$ in accordance with our study. According to this, it is possible to suggest that the nurses had the necessary sensitivity about the incident and error reporting; the nurses exhibited adequate attitudes and behaviors. Rizalar et al.(38)found that the scores of the nurses on the staff training subdimension were generally low (2.59 \pm 0.73$)$. In the study of Erdağı and Özer(42) the lowest mean score of the nurses was on the staff training subdimension of the PSCS $(2.45 \pm 0.61)$. Our study findings were similar to the findings of these studies. One of the most emphasized areas within the framework of the quality studies is the training of employees. Therefore, low level of staff training is not an expected condition. It is considered that providing training to staffs of institutions to improve the safety culture in institutions is an important step in terms of the functionality of the culture.

\section{CONCLUSION}

In a conclusion, it was found that the attitudes of the nurses about medical errors $(3.02 \pm 0.44)$ were generally positive; their patient safety culture perception $(2.71 \pm 0.27)$ was slightly above the medium level. A significant relationship was found between the attitudes of nurses about medical errors and patient safety culture. In this study, the error rate of pediatric nurses in pediatric clinic were found to be $19.1 \%$ while their rates of witnessing an error rate was found as $36.8 \%$. For the pediatric nurses, it is considered that these rates should be further reduced and error tendency should be much lower. For this reason, importance should be given to orientation and in-service training programs and safe communication issues related to the drug administrations and pediatric dose drug calculations taking into account the development and physical characteristics of pediatric patients in order to eliminate or minimize the medical errors. Reporting of errors and events, improvement of care environments, adequate number of nurses, regulation of working hours and appointment of specialized nurses provide benefit. Adding the subject of patient safety to the curriculum of nursing education and raising the awareness of patients about patient safety are beneficial. In addition, the number of studies for analyzing nurses' attitudes about medical errors and patient safety culture should be increased. The information obtained about the nurses' attitudes about medical errors and their patient safety culture was based on their statements; no observation could be made about this. The results can be only generalized to the nurses in the study group.

\section{REFERENCES}

[1] Kaya S. What is patient safety culture and how can it be developed? JPS 2009; 1:32-34. (in Turkish)

[2] Gallagher TH, Waterman AD, Garbutt JM, Kapp JM, Chan DK, Dunagan WC, Fraser VJ, Levinson W. USand Canadian physican's attitudes and experiences regarding disclosing errors to patients. Arch Intern Med 2006;166:1605-1611.

[3] Hellings J, Schrooten W, Klazinga N, Vleugels A.Challenging patient safety culture: survey results. IJHCQA 2007; 20(7):620632.

[4] Tütüncü Ö, Küçükusta D. Patient safety culture and nursing practice. J Hospt Mang2006; 10(2):61-68.

[5] Çırpı F, Doğan Merih Y, Yaşar Kocabey M. Nursing practices that are aims to patient safe and determining the nurses point view of this topic. Maltepe Unv J Nurs Sci Art 2009; 2(3):2634. (Turkish) 
[6] Mitchell PM. Defining patient safety and quality care. Hughes RG, editor. Patient Safety and Quality: An Evidence-Based Handbook for Nurses (Serial Online) 2008 (cited 2019 Mar 7) Available from: URL: http://www.ncbi.nlm.nih. gov/books/ NBK2681/

[7] İzettin FV, Apikoğlu Rabuş Ş, Okuyan B, Sancar M. Drug safety. Sur, H., Palteki T. (Ed.). Hospital Management. Istanbul: Nobel Medical Bookstores; 2013. p. 561-576. (in Turkish)

[8] Bodur S, Filiz E. Validity and reliability of Turkish version of 'hospital survey on patient safety culture' and perception of patient safety in public hospitals in Turkey. BMC Health Serv Res 2010; 10:28: 1-9.

[9] Kohn LT, Corrigan JM, Donaldson MS. To err is human: Building a safer health system. Institute of Medicine, Washington: The National Academy Pres; 2000. P. 86-101.

[10] Joint Commission on Accreditation of Healthcare Organizations (JCAHO). Sentinel Event Statistics, 2006 (cited 2019 May 11). Available from http://www.jointcommission.org/sentinel event.aspx.

[11] Wong J, Beglarya B. Strategies for hospitals to Improve patient safety: A Review of the Research, 2004. (cited 2019 May 15). Available from: https://www.dphu.org/uploads/ attachements/books/books 331 0.pdf.

[12] Schoen C, Osborn R, Huynh PT, Doty M, Zapert K, Peugh J, Davis K. Taking the pulse of health care systems: experiences of patient with health problems in six countries. Health Aff 2005; 16: 509-525

[13] Özkan S. Pediatrik ilaç hazırlama ve uygulamada yapılan hataların önlenmesine yönelik hemşirelik stratejinin geliştirilmesi. Dokuz Eylül Üniversitesi Sağlık Bilimleri Enstitüsü Çocuk Sağlığı ve Hastalıkları Hemşireliği Anabilim Dalı, Doktora Tezi, 2010. (in Turkish)

[14] Fortescue EB, Kaushal R, Landrigan CP, McKenna KJ, Clapp $M D$, Federico F, Goldman DA, Bates DW. Prioritizing strategies for preventing medication errors and adverse drug events in pediatric inpatients. Pediatrics 2003;111: 722-729.

[15] Johnstone MJ, Kanitsaki O. Clinical risk management and patient safety education for nurses: acritique. Nurse Educ Today 2007;27: 185-191.

[16] Başbakkal Z, Taş F, Yılmaz HB. Examination of the opinions of nurses working in pediatric clinics on patient safety culture. Ege Pediatr Bult 2009;16: 87-93. (in Turkish)

[17] Akalın E, Çakmakçı M. Hemşirelikte Hasta Güvenliği: Türkiye ve Dünya Kitabında. Füsun Sayek TTB Raporları Kitapları. Ankara: Türk Tabipler Birliği Yayınları 2011: 36-42. (Turkish)

[18] Altındiş S. Incident reporting in health services and effects on patient safety. JPQH 2010; 1: 17-32.

[19] Dursun S, Bayram N, Aytaç S. An application on patient safety culture. J Soci Sci 2010; 8(1):1 - 14.

[20] Gülec D, Intepeler S.S. Developing a scale of attitudes towards medical errors. HEMARGE 2013; 15: 26-41. (in Turkish)

[21] Türkmen E, Baykal Ü, Seren Ş, Altuntaş S. Development of Patient Safety Culture Scale. Ant J Nurs Health Sci 2011;14(4):38-46. (in Turkish)

[22] Gök D. Pediatri hemşirelerinin ilaç hatalarını bildirme durumları ile tıbbi hatalardaki tutumları arasındaki ilişki. İzmir Kâtip Çelebi Üniversitesi Sağlık Bilimleri Enstitüsü Hemşirelik Anabilim Dalı, Yüksek Lisans Tezi, 2015. (in Turkish)

[23] Ersun A, Başbakkal Z, Yardımcı F, Muslu G, Beytut D. Analysis of medical error tendency of child nurses. J Ege Unv Nursing Faculty 2013; 29:33-45 (in Turkish)
[24] Mayo AM, Duncan D. Nurse perceptions of medication errors: what we need to know for patient safety. J Nurs Care Qual 2004; 19:209-217

[25] Özkan S, Kocaman G, Öztürk C, Seren S. Frequency of pediatric medication administration errors and contributing factors. J Nurs Care Qual 2011;26(2):136-143.

[26] Özata M, Altunkan H. Hemşirelerin Tıbbi Hataya Eğilim Ölçeğinin geliştirilmesi ve geçerlilik güvenirlilik analizinin yapılması. Kırılmaz E, editör. II. Uluslararası Sağlıkta Performans ve Kalite Kongresi Bildiri Kitabı; 201028 Nisan - 01 Mayıs; Sağlık Bakanlığı Yayınları; Ankara: Türkiye; 2010. pp.3-20

[27] Ghaleb MA, Barber N, Franklin BD, Wong IC. The Incidence and nature of prescribing and Medication Administration Errors in Pediatric Inpatients. Arch Dis Child 2010;95(2):113-118.

[28] Young HM, Gray SL, McCormick WC, Sikma SK, Reinhard S, Trippett LJ, Christlieb C, Allen T,Types, Prevalence, and potential clinical significance of medication administration errors in assisted living. J Am Geriatr Soc 2008; 56(7): 11991205.

[29] Madegowda B, Hill PD, Anderson MA. Medication errors in a rural hospital. MEDSURG Nursing 2007; 16(3): 175-180.

[30] Lan Y, Wang KK, Yu S, , Chen IJ, Wu HF, Tang FI. Medication errors in pediatric nursing: assesment of nurses' knowledge and analysis of the consequences of errors. Nurse Edu Tod 2014;34:821-828.

[31] Sears K, Pallas LO, Stevens B, Murphy GT. The relationship between the nursing work enviroment and occurrence of reported paediatric medication administration errors: a pan Canadian study. J Pediatr Nurs 2013;28:351-356.

[32] You M, Choe M, Park G, Kim S, Son Y. Perceptions regarding medication administration errors among hospital staff nurses of South korea. IJQHC 2015;1-8.

[33] Parry AM, Barriball KL, While AE. Factors contributing to registered nurse medication administration error: a narrative reviw. IJNS 2015;52:403-420.

[34] Chang KY, Mark B. Antecedents of severe and nonsevere medication errors. JNS 2009;41(1):70-78.

[35] Özkan S, Kocaman G, Öztürk C. Effectiveness of methods to prevent drug administration errors in children. Turk Arch Pediatr 2013;299-302. (in Turkish)

[36] Töruner EK, Uysal G. Causes, reporting, and prevention of medication errors from a pediatric nurse perspective. Aust J Adv Nurs 2012;29(4): 29-35.

[37] Ateş Ç. Bir Eğitim ve Araştırma Hastanesinde Hemşirelerin İlaç Uygulama Hataları ve Hata Nedenlerinin Belirlenmesi, Gazi Üniversitesi Sağlık Bilimleri Enstitüsü Hemşirelik Programı, Yüksek Lisans Tezi, 2010. (in Turkish)

[38] Rızalar S, Büyük E, Şahiwn R, As T, Uzunkaya G. H. Patient safety culture and Influencing factors of nurses. Dokuz Eylül Unv Faculty Nursing Elect J 2016;9(1):9-15. (cited 2019 May 15). Available from: http://www.deuhyoedergi.org/index. php/DEUHYOED /article/ view/ 157 (Turkish)

[39] Ertürk C, Dönmez P, Özmen D. Assessment of nurses' perceptions of patient safety culture in hospitals in Manisa city center. J Ege Unv Fac Nurs 2016;32(1):19-33. (in Turkish)

[40] Karaca A, Arslan H. A study on evaluation of patient safety culture in nursing services. J Health Nurs Mang2014:1(1).

[41] Özdemir H. Cerrahi Hemşirelerinde Hasta Güvenliği Kültürü Algılarının Belirlenmesi. Afyon Kocatepe Üniversitesi Sağlık 
Bilimleri Enstitüsü Cerrahi Hastalıkları Anabilim Dalı, Yüksek Lisans Tezi, 2014. (in Turkish)

[42] Erdağı S, Özer N. Investigation of working environments, perceptions of patient safety culture and burnout status of nurses working in surgical clinics. Ant J Nurs Health Sci2015;18:94-106.

[43] Türk I, Akgül S, Seçkin M, Tekingündüz S, Zekioğlu A. A study on the patient safety culture: Example of training and research hospital. Health Care Acad 2018; 5(1):25-34. 